\title{
PENGARUH VARIABEL MAKRO EKONOMI TERHADAP TABUNGAN NASIONAL DI INDONESIA
}

\author{
Oleh: \\ Diah Okta Ayuningtyas \\ Staff PT. BPR Wilis Putra Utama Banyuwangi \\ E-mail/No. Hp: nE_noL25@yahoo.com/085233458525
}

\begin{abstract}
This research aim to know the influence of macro economics variables to national saving in Indonesia and also most dominant influence to national saving in Indonesia. Method which is used in this research is double linear regression Partial Adjustement Model used for perceiving short-range and long-range responsivenees from dependent variable to one changed unit of independent variable value. From result of examination obtained real rate of interest and previous period of the national saving individually having influence significantly to the level of national saving. The influence variable to the level of national saving is the level of previous period national saving model because analysis model that used is adjustment of partial model. Outside independent variable, in the reality variable that influencing to the level of national saving is national income.
\end{abstract}

Keywords : macro economics, national saving in Indonesia

\section{PENDAHULUAN}

Indonesia sebagai negara berkembang menyadari akan pentingnya pembangunan dan berusaha untuk mewujudkan kesejahteraan bangsa. Pembangunan ini tidak hanya untuk mewujudkan kesejahteraan materiil (lahiriah) saja, tetapi juga kesejahteraan immateriil (rohaniah). Diharapkan dalam pembangunan rakyat ikut berperan serta secara aktif dan positif, karena partisipasi rakyat merupakan dasar bagi keberhasilan pembangunan.

Pembangunan ekonomi merupakan sebagian dari keseluruhan usaha pembangunan. Secara definitif, pembangunan diartikan sebagai suatu proses yang menyebabkan pendapatan perkapita penduduk masyarakat meningkat dalam jangka panjang. Pembangunan ekonomi di negara-negara berkembang (developing countries) termasuk didalamnya pertumbuhan ekonomi yang cukup tinggi, memiliki dana yang cukup besar. Tetapi di sisi lain, usaha pengerahan sumber dana dalam negeri untuk membiayai pembangunan menghadapi kendala dalam pembentukan modal baik yang bersumber dari penerimaan pemerintah yaitu ekspor barang dan jasa ke luar negeri, ataupun penerimaan pemerintah melalui instrumen pajak.

Di Indonesia, untuk membiayai pembangunan nasional yang mencakup investasi domestik, sumber dananya dapat bersumber dari tabungan nasional dan pinjaman luar negeri. Namun, karena terbatasnya jumlah dana serta pinjaman yang diperoleh dari luar negeri, maka diperlukan tabungan nasional yang lebih tinggi sebagai sumber dana yang utama. (Wahid Saputra, 2008).

Perlunya tabungan nasional ini dibuktikan dengan adanya savinginvestment gap yang semakin melebar dari tahun ke tahun yang menandakan 
bahwa pertumbuhan investasi domestik melebihi kemampuan dalam mengakumulasi tabungan nasional. Secara umum, usaha pengerahan modal dari masyarakat dapat berupa pengerahan modal dari dalam negeri maupun dari luar negeri. Pengklasifikasian ini didasarkan pada sumber modal yang dapat digunakan dalam pembangunan.

Pengerahan modal yang bersumber dari dalam negeri berasal dari 3 sumber utama, yaitu : pertama, tabungan sukarela masyarakat. Kedua, tabungan pemerintah, dan ketiga tabungan paksa (forced saving or involuntary saving). Sedangkan modal yang berasal dari luar negeri yaitu melalui pinjaman resmi pemerinyah kepada lembaga-lembaga keuangan internasional seperti International Monetary Fund (IMF), Asian Development Bank (ADB), World Bank, maupun pinjaman resmi bilateral dan multilateral, juga melalui foreign direct investment (FDI). (Wahid Saputra, 2008).

Pada Negara Berkembang dan Negara Sedang Berkembang, kondisi yang paling menonjol adalah belum terciptanya kondisi yang mendorong pada iklim dimana kegairahan untuk menabung dan penanaman modal menunjukan tingkat yang menggembirakan. Oleh karenanya kesadaran menabung harus ditanamkan kepada seluruh masyarakat baik pria atau wanita, tua atau muda. Dengan menabung dapat diperoleh manfaat ganda, yaitu di satu pihak tabungan dapat sebagai modal pembangunan dan di pihak lain menabung akan menumbuhkan kebiasaan hidup sederhana. Dengan jumlah tabungan yang tinggi dari masyarakat, negara kita yang masih dalam tahap melaksanakan pembangunan ekonomi ini akan dapat mengurangi ketergantungan terhadap pinjaman atau bantuan luar negeri.
Menurut Achmad Subianto (2005) poin utama yang wajib untuk diperhatikan sebagai ukuran kesuksesan sebuah negara dalam merencanakan masa depannya adalah berdasarkan skala tabungan nasional bangsa dari segala bidang (baik dari dana pensiun, tabanas dan sebagainya), yang dimaksud tabungan nasional adalah sejumlah dana yang berhasil dihimpun oleh pemerintah baik dari sektor swasta maupun sektor pemerintah itu sendiri dalam waktu tertentu yang di kemudian hari ditujukan untuk pendanaan kebutuhan nasional, khususnya untuk menjaga stabilitas kondisi perekonomian suatu bangsa (selain itu biasanya juga digunakan uuntuk pendanaan pembangunan, dan lain sebagainya).

Kalau ditilik dari sejarah Perekonomian Indonesia, pemerintah pernah menetapkan Paket Kebijakan Oktober 1988 atau yang lebih dikenal dengan "PAKTO 88", yang pokokpokok kebijakannya berisi antara lain untuk mengerahkan dana dari masyarakat dengan cara memudahkan pembukaan kantor cabang baru, pendirian bank swasta baru, keleluasaan penyelenggaraan tabungan, dan perluasan kantor cabang bank. Setelah adanya "PAKTO 88" ini, semakin mudahlah bank didirikan dan semakin bervariasi juga bentuk-bentuk tabungan yang ditawarkan oleh bank-bank yang sudah terbentuk baik swasta maupun pemerintah.

Semenjak saat itu, tabungan nasional mulai meningkat drastis. Dalam tahun-tahun sebelumnya tampak adanya kecenderungan persaingan antar berbagai negara untuk memperbesar arus investasi baik asing maupun domestik. Persaingan terutama terjadi karena kebutuhan dana yang sangat besar dan mendesak untuk mendukung pertumbuhan ekonomi terutama di negara-negara berkembang. 
Selain itu pemerintah pernah berusaha untuk menggerakkan minat masyarakat dalam menabung lewat Gerakan Tabungan Nasional, atau Tabanas. Walaupun gerakan ini pernah menjadi cukup efektif, tetapi semakin lama makin meredup seiring dengan kecenderungan pola hidup masyarakat yang semakin konsumtif. (Marvel, 2006).

Ketidakcukupan tabungan nasional dalam menjaga kestabilan perekonomian Indonesia terbukti pada tahun 1997, dimana Indonesia terpaksa harus bergantung pada pinjaman World Bank dan IMF. Lain dengan Malaysia, salah satu negara tetangga yang secara konsisten menjaga cadangan devisa-nya (tidak lain salah satunya berupa tabungan nasional), hingga bisa recover secara cepat dari Asian Crisis waktu itu. Bahkan Malaysia dapat keluar dari krisis dalam waktu singkat tanpa bantuan dari negara lain.

Ada dua mekanisme yang dapat dilakukan pemerintah dalam menghimpun tabungan nasional dari sisi masyarakat. Secara jangka pendek dapat dengan menggunakan mekanisme perbankan, karena fluktuatif (dapat diambil kapan pun). Sedangkan secara jangka panjang dapat dengan mekanisme dana pensiun, asuransi, dan program jaminan sosial jangka panjang.

Di sinilah arti pentingnya pembentukan modal dalam negeri yaitu melalui peningkatan tabungan, dalam hal ini tabungan nasional. Meskipun perubahan yang akan ditimbulkan tidak secepat bila menggunakan modal luar negeri, tetapi kita tidak terbebani oleh masalah-masalah baru yang akan timbul di kemudian hari Berdasarkan latar belakang masalah di atas, permasalahan yang dikaji dalam penelitian ini adalah 1) Seberapa besar pengaruh variabelvariabel makro ekonomi terhadap tabungan nasional di Indonesia? 2)Dari variabel-variabel makro ekonomi tersebut, variabel manakah yang berpengaruh secara dominan terhadap tabungan nasional di Indonesia?

\section{TINJAUAN PUSTAKA}

Menurut pendapat ahli-ahli ekonom Klasik (dalam Sadono Sukirno, 2004:70) dalam suatu perekonomian yang diatur oleh mekanisme pasar tingkat penggunaan tenaga kerja penuh akan selalu tercapai. Pandangan ini didasarkan pada keyakinan bahwa di dalam perekonomian tidak akan terdapat kekurangan permintaan. Apabila para produsen menaikkan produksi mereka maka dalam perekonomian akan selalu terdapat permintaan terhadap barangbarang tersebut.

Keyakinan ahli-ahli Klasik bahwa penawaran akan selalu menciptakan permintaan dapat dengan jelas dilihat dari pandangan Jean Baptiste Say (17671832). Ia mengatakan: "Supply creates its own demand". Kebenaran pendapat ini tidak dapat disangkal dalam suatu perekonomian yang terdiri dari dua sektor dimana penerima-penerima pendapatan tidak menabung dan para pengusaha tidak menanamkan modal.

Namun dalam perekonomian yang lebih maju, dimana penerima-penerima pendapatan akan menyisihkan sebagian pendapatan mereka untuk ditabung, ahliahli ekonomi Klasik tetap berkeyakinan bahwa walaupun rumah tangga akan menabungkan sebagian dari pendapatan yang diperolehnya, kekurangan dalam permintaan tidak akan terjadi dalam perekonomian. Keyakinan itu didasarkan kepada pandangan yang pada hakikatnya mengatakan bahwa semua tabungan sektor rumah tangga yang tercipta pada tingkat penggunaan tenaga kerja penuh akan digunakan oleh para pengusaha untuk investasi. 
Menurut ahli-ahli ekonomi Klasik (dalam Sadono sukirno, 2004:73), mengatakan bahwa:

"Dalam perekonomian suku bunga akan selalu mengalami perubahan. Dan perubahan itu akan menyebabkan seluruh tabungan yang diciptakan sektor rumah tangga pada waktu perekonomian mencapai tingkat pengunaan tenaga kerja penuh akan selalu sama besarnya dengan jumlah investasi yang dilakukan oleh para pengusaha. Oleh karenanya jumlah seluruh pengeluaran dalam perekonomian (pengeluaran agregat), yang meliputi konsumsi oleh rumah tangga dan investasi oleh para pengusaha, akan selalu sama dengan nilai seluruh produksi yang diciptakan oleh seluruh sektor perusahaan pada tingkat penggunaan tenaga kerja penuh".

Selanjutnya menurut ekonom Klasik, jumlah tabungan ditentukan oleh suku bunga. Oleh karena perkonomian selalu mencapai penggunaan tenaga kerja penuh, jumlah tabungan yang diwujudkan adalah jumlah tabungan ketika perekonomian mencapai tingkat pengunaan tenaga kerja penuh. Hal ini dapat dilihat pada gambar 1 dimana gambar tersebut menunjukkan: (a) apabila tingkat bunga adalah $\mathrm{r}_{0}$ jumlah tabungan adalah $\mathrm{S}_{0}$ dan (b) apabila suku bunga adalah $r_{1}$ jumlah tabungan adalah $\mathrm{S}_{1}$. Dengan demikian grafik tersebut menunjukkan pandangan Klasik yang menyatakan makin tinggi suku bunga makin banyak tabungan yang akan dilakukan masyarakat. Begitu pula sebaliknya makin rendah tingkat suku bunga maka makin sedikit tabungan yang akan dilakukan masyarakat.

Menurut Keynes (dalam Sadono Sukirno, 2004:80), besarnya tabungan yang dilakukan oleh rumah tangga bukan tergantung kepada tinggi rendahnya suku bunga. Namun tergantung kepada besar kecilnya tingkat pendapatan rumah tangga itu. Makin besar jumlah pendapatan yang diterima oleh satu rumah tangga, makin besar pula jumlah tabungan yang akan dilakukan olehnya. Apabila jumlah pendapatan yang diterima oleh satu rumah tangga itu tidak mengalami kenaikan atau penurunan, perubahan yang cukup besar dalam suku bunga tidak akan menimbulkan pengaruh yang berarti terhadap jumlah tabungan yang akan dilakukan oleh rumah tangga itu.

Teori permintaan uang sebenarnya dapat dijelaskan dengan mengunakan teori tentang alokasi sumber-sumber ekonomi yang sifatnya terbatas. Pada prinsipnya, dengan sumber ekonomi yang terbatas, manusia haruslah memilih alokasi yang memberikan kepuasan yang sebesar-besarnya. Dengan pendapatan tertentu, apabila seseorang ingin memperbanyak konsumsi maka jumlah kekayaan akan semakin kecil. Demikian juga apabila dia ingin memiliki salah satu kekayaan lebih banyak maka dengan sendirinya pemilikan bentuk kekayaan yang lain akan menjadi lebih sedikit.

Untuk mengantisipasi hal tersebut, seseorang akan membandingbandingkan hasil (return) dari masingmasing kekayaan. Dari hasil tersebut dia akan menentukan komposisi dan proporsi dari masing-masing bentuk kekayaan agar diperoleh hasil yang maksimum. Kekayaan dapat berwujud uang, surat berharga, deposito atau barang. Jadi teori permintaan uang pada dasarnya ingin menjawab pertanyaan mengapa atau alasan-alasan apa yang menyebabkan seseorang memilih kekayaannya dalam bentuk uang kas. Dalam hal ini akan diterangkan beberapa teori permintaan uang yaitu: 
Teori permintaan uang Klasik (dalam Nopirin, 1986:124) bermula dari teori tentang jumlah uang yang beredar dalam masyarakat (teori kuantitas uang). Teori ini tidak dimaksudkan menjelaskan mengapa seorang atau masyarakat menyimpan uang kas, tetapi lebih pada peranan uang dalam perekonomian. Dengan sederhana Irving Fisher merumuskan teori kuantitas uang sebagai berikut:

$\mathrm{MV}=\mathrm{PT}$

Dimana, $\mathrm{M}=$ Jumlah uang beredar; $\mathrm{V}=$ Perputaran uang dari satu tangan ke tangan lain dalam satu periode; $\mathrm{P}=$ Harga barang; $\mathrm{T}=$ Volume barang yang diperdagangkan.

Menurut kaum Klasik pendapatan nasional akan selalu dalam keadaan full employment dimana keinginan masyarakat untuk menabung sama dengan keinginan perusahaan untuk melakukan investasi. Dalam kenyataannya tabungan selalu sama dengan investasi. Namun tabungan sama dengan investasi bukanlah merupakan syarat adanya keseimbangan dalam pendapatan nasional yang selalu dalam keadaan full employment. Keynes membantah keadaan ini dan menyatakan bahwa pendapatan nasional yang seimbang dapat terjadi pada keadaan kurang dari full employment.

Menurut Klasik (dalam Yuni, 2001:16) akibat dari keadaan dimana keinginan menabung lebih besar daripada keinginan investasi akan terjadi perubahan harga. Karena sektor perusahaan tidak bisa menjual output yang direncanakan, maka mereka akan menurunkan harga outputnya sampai semua persediaan yang tak diinginkan terjual habis, buruh akan menurunkan tuntutan upahnya, dan tingkat bunga juga akan turun karena keinginan menabung lebih besar dari pada keinginan investasi. Turunnya tingkat bunga ini akan menurunkan keinginan menabung dan mendorong untuk melakukan investasi dan sektor perusahaan kembali pada produksi full employment.

Sedangkan keynes mengajukan penyelesaian yang berbeda. Menurut Keynes (dalam Nopirin, 1990:79) harga barang relatif tetap dan mungkin tidak turun meskipun terdapat kelebihan persediaan barang. Demikian pula upah, sangat sukar untuk turun mungkin karena adanya tantangan dari serikat buruh dan yang lebih pentng lagi, bahwa tingkat bunga tidaklah dapat menyamakan tabungan dan investasi. Tingkat bunga ditentukan di dalam pasar uang yang membuat permintaan akan uang sama dengan penawarannya.

Keynes juga menambahkan apabila sektor perusahaan mengalami tambahan persediaan yang tidak diinginkan, pengusaha akan memperkecil atau mengurangi produksi. Output akan turun selama keinginan menabung lebih besar daripada keinginan untuk investasi. Proses turunnya output itu akan terus berlangsung sampai keinginan menabung sama dengan keinginan investasi, dimana pendapatan nasional keseimbangan yang baru, lebih rendah dari semula. (Nopirin, 1990:80).

Hubungan tingkat bunga dan tabungan nasional dapat dijelaskan oleh teori tingkat bunga baik Klasik maupun Keynes. Pada dasarnya teori ini berpendapat sama bahwa tingkat bunga dapat mempengaruhi tabungan dengan hubungan yang positif, artinya kenaikan tingkat bunga akan diikuti dengan kenaikan tabungan, hanya berbeda dalam asumsi yang digunakan. Klasik menyebutkan bahwa tinggi (rendah) tingkat bunga ditentukan oleh permintaan dan penawaran akan modal, sedangkan Keynes berpendapat bahwa tingkat bunga ditentukan oleh permintaan dan penawaran uang. 
Ahli-ahli ekonomi Klasik (dalam Sadono Sukirno, 2004:73) berkeyakinan bahwa perubahan-perubahan yang dapat dengan mudah berlaku atas suku bunga akan menjamin terciptanya kesamaan diantara jumlah tabungan yang akan disediakan rumah tangga dan jumlah investasi yang akan dilakukan oleh pengusaha. Hal ini dikarenakan menurut pendapat mereka keadaan seperti itu akan terjadi karena suku bunga menentukan besarnya tabungan maupun investasi yang akan dilakukan dalam perekonomian. Setiap perubahan dalam suku bunga akan menyebabkan perubahan pula dalam tabungan rumah tangga dan permintaan dana untuk investasi perusahaan. Perubahanperubahan dalam suku bunga akan terusmenerus berlangsung sebelum kesamaan di antara jumlah tabungan dengan jumlah permintaan dana investasi tercapai.

\section{METODE PENELITIAN}

Beberapa variabel yang digunakan dalam penelitian ini diberi batasan sebagai berikut: Variabel dependen, LS : Log Tabungan nasional, dalam hal ini digunakan Produk Nasional Bruto dikurangi total konsumsi rumah tangga. Digunakan data triwulanan yang dipublikasikan oleh Bank Indonesia untuk tahun 1997-2007 dimana data ini akan di log-kan terlebih dahulu sebelum diregresikan.

Variabel Independen, LY : Log Pendapatan nasional disini diartikan sebagai Produk Domestik Bruto, yaitu total output yang diproduksi suatu negara baik oleh warga negara dalam negeri maupun warga negara yang tinggal di luar negeri. Data diambil dari Statistik Ekonomi Keuangan Indonesia yang dikeluarkan oleh Bank Indonesia. Data yang digunakan adalah data PDB atas dasar harga konstan triwulanan pada tahun 1997-2007. PDB atas dasar harga konstan, dimana data ini akan di log-kan terlebih dahulu sebelum diregresikan.

Lr: Tingkat bunga yang dipergunakan adalah tingkat bunga riil yamg merupakan tingkat suku bunga yang dikoreksi dengan pengaruh inflasi. Digunakan data tingkat suku bunga deposito 1 bulan yang dipublikasikan oleh Bank Indonesia. Data yang digunakan dalam bentuk triwulanan untuk tahun 1997-2007. Tingkat suku bunga riil ini di log-kan terlebih dahulu sebelum diregresikan.

LSt-1: Log Tabungan Nasional periode sebelumnya merupakan syarat utama dalam perhitungan model PAM. Dalam hal ini tabungan nasional sebelumnya adalah uang giral pada periode sebelumnya dimana data ini akan di log-kan terlebih dahulu sebelum diregresikan. Data ini diperoleh dari Statistik Ekonomi dan Keuangan Indonesia.

Spesifikasi model dinamik merupakan satu hal yang penting dalam pembentukan model ekonomi dan analisis yang menyertainya. Hal ini karena sebagian besar analisis ekonomi berkaitan erat dengan analisis runtun waktu (time series) yang sering diwujudkan oleh hubungan antara perubahan suatu besaran ekonomi di saat yang lain. Hubungan semacam ini telah banyak dicoba untuk dirumuskan dalam Model Linier Dinamik (MLD). Namun tidak dapat dipungkiri bahwa sampai saat ini belum terdapat kesepakatan mengenai model dinamik mana yang paling sesuai untuk analisis ekonomi. Kelangkaan akan adanya kesepakatan tersebut dikarenakan adanya banyak faktor yang berpengaruh dalam pembentukan model tersebut; misalnya pengaruh faktor kelembagaaan, peranan penguasa ekonomi dan pandangan si pembuat model mengenai gejala dan situasi ekonomi yang menjadi pusat perhatiannya. (Maria, 2003:33) 
Menurut Damodar Gujarati (1999:98) dalam praktik analisis data, banyak peneliti sering terkecoh oleh nilai $\mathrm{R}^{2}$ yang begitu meyakinkan dan kurang tanggap akan uji diagnostik atau uji terhadap asumsi klasik (terutama autokorelasi, heteroskedastisitas dan linearitas) dari alat analisis yang digunakan. Padahal $\mathrm{R}^{2}$ yang tinggi hanyalah salah satu kriteria dipilihnya suatu persamaan regresi. Namun $R^{2}$ bukanlah merupakan suatu syarat untuk mengamati baik atau tidaknya perumusan suatu model. Karena sebenarnya dengan tingginya nilai $\mathrm{R}^{2}$ dari hasil regresi atau estimasi suatu model merupakan peringatan bahwa hasil estimasi tersebut terkena regresi lancung (spurious regression).

Sehubungan dengan permasalahan di atas dan selaras dengan perkembangan metode ekonometri, ada dua metode yang dapat digunakan untuk menghindari regresi lancung. Pertama, tanpa uji stasioneritas data, yaitu dengan membentuk MLD seperti Model Autoregresif Distributed Lag (Autoregressive Distributed Lag Model), Model Koreksi Kesalahan (Error Correction Model = ECM), Model Penyesuaian Parsial (Partial Adjusment Model = PAM), Model Cadangan Penyangga (Buffer Stock Model = BSM) atau Model Penyerap Syok (Shock-Absorber Model = SAM), Model Koreksi Kesalahan dari Insukindro (Insukindro-Error Correction Model = IECM). Penggunaan MLD selain dapat terhindar dari regresi lancung juga bisa digunakan untuk mengamati atau melihat hubungan jangka panjang antar variabel seperti yang diharapkan oleh teori yang bersangkutan. Metode kedua adalah dengan menggunakan uji stasionaritas data. Uji ini pada dasarnya merupakan pengujian terhadap teori dan merupakan bagian penting dalam perumusan dan estimasi MLD.
Untuk mengetahui pengaruh variabel makro ekonomi terhadap tabungan nasional metode regresi berganda. Dalam penelitian model awal yang digunakan dalam penelitian ini adalah sebagai berikut:

$\mathrm{S}_{\mathrm{t}}^{*}=\alpha_{0}+\alpha_{1} \mathrm{Y}_{\mathrm{t}}+\alpha_{2} \mathrm{r}+\mathrm{e}_{\mathrm{t}}$

Dimana, $\mathrm{S}_{\mathrm{t}}^{*}=$ Tabungan nasional jangka panjang; $\mathrm{Y}_{\mathrm{t}}=$ Pendapatan Nasional; $\mathrm{r}=$ Tingkat Suku Bunga Riil; $\alpha_{0}, \alpha_{1}, \alpha_{2}, \alpha_{3}=$ Konstanta; $\mathrm{e}_{\mathrm{t}}=$ error term.

Karena nilai dari tabungan nasional optimal $\mathrm{S}_{\mathrm{t}}$ * tidak didapatkan datanya di lapangan maka dideteksi melalui penyesuaian persediaan atau Partial Adjustment Model (PAM). Jika $\mathrm{St}^{*}$ adalah tabungan nasional optimal pada periode $t$ dan $S_{t}$ adalah nilai actual tabungan nasional maka model penyesuaian persediaan atau PAM dapat dijelaskan sebagai berikut

$$
\begin{aligned}
\mathrm{S}_{\mathrm{t}}-\mathrm{S}_{\mathrm{t}-1} & =\delta\left(\mathrm{S}_{\mathrm{t}} *-\mathrm{S}_{\mathrm{t}-1}\right) \\
\mathrm{S}_{\mathrm{t}} & =\delta \mathrm{S}_{\mathrm{t}} *+\mathrm{S}_{\mathrm{t}-1-\delta \mathrm{S}_{\mathrm{t}-1}} \\
\mathrm{~S}_{\mathrm{t}} & =\delta \mathrm{S}_{\mathrm{t}} *+(1-\delta) \mathrm{S}_{\mathrm{t}-1}
\end{aligned}
$$

Dimana:

$\mathrm{S}_{\mathrm{t}}{ }^{*}=$ Tabungan Nasional Jangka Panjang; $\delta=$ Koefisien penyesuaian besarnya $0<\delta<1$.

Agar persamaan (1) dapat dicari solusinya maka persamaan disubstitusikan ke dalam persamaan (2) sehingga menghasilkan persamaan sebagai berikut:

$\mathrm{S}_{\mathrm{t}}=\delta\left(\alpha_{0}+\alpha_{1} \mathrm{Y}_{\mathrm{t}}+\alpha_{2} \mathrm{r}+\mathrm{e}_{\mathrm{t}}\right)+(1-\delta) \mathrm{S}_{\mathrm{t}-1}$

$\mathrm{S}_{\mathrm{t}}=\delta \alpha_{0}+\delta \alpha_{1} \mathrm{Y}_{\mathrm{t}}+\delta \alpha_{2}+(1-\delta) \mathrm{S}_{\mathrm{t}-1}+\delta \mathrm{e}_{\mathrm{t}}$

$\mathrm{S}_{\mathrm{t}}=\delta \alpha_{0}+\delta \alpha_{1} \mathrm{Y}_{\mathrm{t}}+\delta \alpha_{2} \mathrm{r}+(1-\delta) \mathrm{S}_{\mathrm{t}-1}+$

$$
v_{t}
$$

Dimana $: v_{t}=\delta e_{t}$

Jika:

$\delta \alpha_{0}=\beta_{0}$

$\delta \alpha_{1}=\beta_{1}$

$\delta \alpha_{2}=\beta_{2}$

$\delta \alpha_{3} \quad=\beta_{3}$

maka persamaan (3) menjadi:

$S_{t}=\beta_{0}+\beta_{1} Y_{t}+\beta_{2} r+\beta_{3} S_{t-1}+\mu_{t}$

Dimana: 
$\mathrm{S}_{\mathrm{t}}=$ Tabungan Nasional Jangka Pendek; $\mathrm{Y}_{\mathrm{t}}=$ Pendapatan Nasional; $\mathrm{r}=$ Tingkat Suku Bunga Riil; $\beta_{0}, \beta_{1}, \beta_{2}, \beta_{3}=$ Konstanta; $\mu_{\mathrm{t}}=$ error term

Agar data berbentuk linier maka dalam penelitian ini semua variabel dilogkan terlebih dahulu sehingga model persamaan jangka pendek menjadi

$\mathrm{LS}_{\mathrm{t}}=\beta_{0}+\beta_{1} \mathrm{LYt}+\beta_{2} \mathrm{Lr}+\beta_{3} \mathrm{LS}_{\mathrm{t}-1}+\mu_{\mathrm{t}}$

\section{Dimana:}

$\mathrm{LS}_{\mathrm{t}}=$ Log Tabungan Nasional Jangka Pendek; $\mathrm{LY}_{\mathrm{t}}=\log$ Pendapatan Nasional; $\mathrm{Lr}=$ Log Tingkat Suku Bunga Riil; $\beta_{0}, \beta_{1}, \beta_{2}, \beta_{3}=$ Konstanta; $\mu_{\mathrm{t}}=$ error term.

Seperti yang terlihat di atas, dalam persamaan regresi linear dimasukkan nilai lag (keterlambatan) variabel terikat sebagai salah satu variabel bebas, sehingga model regresi ini disebut model autoregresif. Dimana dalam model ini melibatkan regresi variabel terikat atas lag variabel itu sendiri untuk periode waktu tertentu. Menurut Damodar Gujarati (1997:255), ada beberapa alasan mengapa model ini digunakan antara lain, yaitu alasan psikologis, teknis dan kelembagaan. Sebagai akibatnya, suatu variabel terikat ekonomis mungkin memerlukan waktu untuk menanggapi suatu variabel penentu yang bersifat ekonomis. Dengan kata lain model, autoregresif ini memperhitungkan secara eksplisit peranan dari waktu yang dapat membantu kita untuk membedakan antara respon jangka pendek dan jangka panjang dari variabel terikat terhadap satu unit perubahan pada nilai variabel bebas. Oleh karena itu, dalam penelitian yang ingin mengetahui pengaruh variabel makro ekonomi terhadap tabungan nasional digunakan model autoregresif yang memasukkan variabel tabungan nasional periode sebelumnya sebagai salah satu variabel bebas dan model di atas dikenal sebagai model penyesuaian parsial (PAM).

Dikarenakan ada kelambanan, maka koefisien jangka panjang dapat diketahui dengan rumus sebagai berikut:

$$
=\frac{\text { Coeficient VariabelBebas }}{(1-\text { Coeficient VariabelLag })}
$$

Untuk mengetahui variabel bebas manakah yang memberi pengaruh paling besar terhadap variabel terikat dilihat dari besarnya probabilitas. Semakin kecil nilai probabilitas, maka semakin besar pula pengaruh yang ditimbulkan variabel bebas tersebut terhadap variabel terikat.

Pada umumya salah satu konsep penting dalam teori ekonometrika adalah anggapan stasioneritas (stationarity). Secara statistik, sebuah data runtun waktu (time series) dikatakan stasioner jika rata-rata dan varians data tersebut konstan dari waktu ke waktu dan nilai kovarian diantara dua periode waktu bergantung hanya pada jarak atau kelambanan antara dua periode waktu tersebut, bukan bergantung pada waktu sesungguhnya saat dihitungnya kovarian.

Uji akar-akar unit dapat digunakan untuk menguji stasionaritas data, karena pada prinsipnya uji tersebut dimaksudkan untuk mengamati apakah koefisien tertentu dari model otoregresif yang ditaksir mempunyai nilai satu atau tidak. Biasanya uji yang dikembangkan oleh Dickey dan Fuller digunakan untuk menentukan stasioner tidaknya data runtun waktu, dengan penaksiran autoregresif berikut ini:

$\mathrm{DX}_{\mathrm{t}}=\mathrm{a}_{0}+\mathrm{a}_{1} \mathrm{~B} \mathrm{X}_{\mathrm{t}}+\sum_{i=1}^{k} \mathrm{~b}_{\mathrm{i}} \mathrm{B}^{\mathrm{i}} \mathrm{D} \mathrm{X}_{\mathrm{t}} \ldots \ldots(1)$

Dimana:

$\mathrm{DX}_{\mathrm{t}}=\mathrm{X}_{\mathrm{t}}-\mathrm{X}_{\mathrm{t}-1} ; \mathrm{BX}_{\mathrm{t}}=\mathrm{X}_{\mathrm{t}-1} ; \mathrm{X}_{\mathrm{t}}=$ Variabel yang diamati pada periode $t$; $B$ $=$ Operasi kelambanan ke hulu (backward lag operator); $\mathrm{k}=\mathrm{N}^{1 / 3}$ dimana $\mathrm{N}$ adalah jumlah observasi. 
Dari persamaan (1) di atas, kemudian dihitung nilai statistik DF (Dickey-Fuller). Nilai DF untuk hipotesis bahwa $\mathrm{a}_{1}=0$ ditunjukkan oleh nisbah t pada koefisien regresi $\mathrm{BX}_{\mathrm{t}}$ pada persamaan diatas. Selanjutnya nilai statistik DF dibandingkan dengan nilai kritisnya, dengan ketentuan sebagai berikut: $\mathrm{DF}_{\text {statistik }}<\mathrm{DF}$ kritis : Terima $\mathrm{H}_{0}$, nonstasioner; $\mathrm{DF}_{\text {statistik }}>\mathrm{DF}_{\text {kritis }}$ : Tolak $\mathrm{H}_{0}$, stasioner

Dari hasil estimasi di atas, didapatkan data yang stasioner pada derajat integrasi yang sama antara variabel yang satu dengan variabel yang lain, yang memungkinkan bagi variabelvariabel tersebut untuk saling berkointegrasi. Hal ini didukung oleh pendapat Insukindro (1993) yang menyatakan bahwa untuk dapat melakukan uji kointegrasi harus diyakini terlebih dahulu bahwa variabel-variabel terkait, telah stasioner pada derajat integrasi yang sama.

Untuk mendapatkan gambaran mengenai uji kointegrasi, anggaplah kita memiliki satu himpunan variabel runtun waktu X. Komponen X dikatakan berkointegrasi pada derajat $\mathrm{d}, \mathrm{b}$ atau ditulis $\sim(\mathrm{d}, \mathrm{b})$ bila: 1) Setiap komponen dari $\mathrm{X}$ berkointegrasi pada derajat $\mathrm{d}$ atau I(d); 2) Terdapat suatu vektor $\alpha$ yang tidak sama dengan nol $(\alpha \neq 0)$, sehingga $\mathrm{Z}_{\mathrm{t}}=\alpha^{1} \mathrm{X} \sim \mathrm{I}(\mathrm{d}, \mathrm{b})$, dimana $\mathrm{b}>0$ dan $\alpha$ adalah vektor kointegrasi.

Implikasi penting dari ilustrasi dan definisi di atas adalah bahwa jika dua variabel atau lebih mempunyai derajat integrasi yang berbeda, katakanlah $\mathrm{X}=$ $\mathrm{I}(1)$ dan $\mathrm{Y}=\mathrm{I}(2)$, maka kedua variabel tersebut tidak dapat berkointegrasi (Insukindro, 1993: 132).

\section{PEMBAHASAN}

Karena sebagian besar analisis ekonomi berkaitan erat dengan analisis runtun waktu (time series) yang sering diwujudkan oleh hubungan antara perubahan suatu besaran ekonomi di saat yang lain, maka dalam penelitian ini digunakan Model Linier Dinamik (MLD). Model persamaan regresi yang digunakan dalam penelitian ini adalah $\mathrm{LS}_{\mathrm{t}}=\beta_{0}+\beta_{1} \mathrm{LY}_{\mathrm{t}}+\beta_{2} \mathrm{Lr}+\beta_{3} \mathrm{LS}_{\mathrm{t}-1}$ Dimana:

LS = Log Tabungan Nasional; LY $=$ Log Produk Domestik Bruto; $\mathrm{Lr}=\log$ Tingkat Suku Bunga Riil; $\mathrm{LS}_{\mathrm{t}-1}=\log$ Tabungan Nasional Periode Sebelumnya; $\beta_{0}, \beta_{1}, \beta_{2}, \beta_{3}=$ Konstanta; $\mathrm{e}_{\mathrm{t}}=$ Standar error.

Dalam hal pembuktian hipotesa maka penulis melakukan pengujian hipotesa serta persamaan regresi secara bersama-sama atau simultan dan parsial, serta melakukan pengujian apakah persamaan yang telah diasumsikan bersifat BLUE (Best Linier Unbiased Estimator).

Uji akar-akar unit yang dilakukan terhadap data tabungan nasional, pendapatan nasional, tingkat suku bunga menggunakan lag dengan rule of thumb $=3$, serta taraf signifikan (significance level) 5\%. Anggapan stasioner diterima bila nilai absolut Dickey-Fuller Statistic variabel-variabel tersebut lebih besar bila dibandingkan dengan nilai kritisnya (MacKinnon Critical Value). Tabel 1 di bawah ini menyajikan hasil pengujian akar-akar unit:

Tabel 1. Hasil Uji Akar-akar Unit (Level): Variabel Tabungan nasional, Pendapatan Nasional, dan Tingkat Suku Bunga Riil

\begin{tabular}{llll}
\hline No & $\begin{array}{c}\text { Variabel } \\
\text { Bebas }\end{array}$ & $\begin{array}{c}\text { Nilai DF } \\
\text { Statistik }\end{array}$ & Kesimpulan \\
\hline 1. & $\begin{array}{l}\text { Tabungan } \\
\text { Nasional }\end{array}$ & -4.3488 & Stasioner \\
2. & $\begin{array}{l}\text { Pendapatan } \\
\text { Nasional }\end{array}$ & -5.0201 & Stasioner \\
3. & $\begin{array}{l}\text { Tingkat } \\
\text { Suku Bunga } \\
\text { Riil }\end{array}$ & -4.1260 & Stasioner \\
& & \\
\hline
\end{tabular}

Sumber : Data diolah, MacKinnon Critical Value $=-1.9498$ 
Dari hasil analisa terhadap data time series dengan uji akar-akar unit tersebut diatas, terlihat bahwa setiap nilai $\mathrm{t}$ hitung $\mathrm{ADF}$ dari masing-masing variabel lebih besar dari $t$ tabel $\mathrm{ADF}$ ( $\mathrm{t}$ hit $\mathrm{ADF}>\mathrm{t}$ tabel ADF), maka dapat disimpulkan bahwa seluruh data time series tersebut dalam keadaan stasioner pada derajat ke dua atau I(2). Karena masing-masing variabel telah stasioner pada derajat integrasi yang sama, maka dapat disimpulkan bahwa variabelvariabel tersebut berkointegrasi, sehingga estimasi terhadap persamaan PAM dapat dilakukan.

Dari hasil pengujian model yang digunakan dalam penelitian ini dapat diketahui bahwa variabel bebas pendapatan nasional, tingkat suku bunga riil dan tabungan nasional periode sebelumnya berpengaruh terhadap variabel terikat tabungan nasional. Hasil pengujian model regresi dapat ditunjukkan sebagai berikut :

Tabel 2. Hasil Estimasi Regresi antara Variabel Independen dan Variabel Dependen Tabungan Nasional

\begin{tabular}{lllll}
\hline $\begin{array}{l}\text { Variabel } \\
\text { Bebas }\end{array}$ & $\begin{array}{l}\text { Koef. } \\
\text { Regresi }\end{array}$ & $\begin{array}{l}\text { Simp. } \\
\text { Baku }\end{array}$ & $\begin{array}{l}\mathrm{T} \\
\text { Hitung }\end{array}$ & Prob. \\
\hline Konstanta & $-8,868$ & 2,155 & $-4,1137$ & \\
& 0,1496 & 0,022 & 6,7073 & 0,0009 \\
$\mathrm{LY}_{\mathrm{t}}$ & 0,0860 & 0,029 & 2,9227 & \\
$\mathrm{Lr}$ & & & & 0,0000 \\
& 1,1983 & 0,078 & & \\
$\mathrm{LS}_{\mathrm{t}-1}$ & & & 15,2672 & 0,0000 \\
\hline
\end{tabular}

Sumber: Data diolah

$\mathrm{R}^{2}=$ Koef. Determinasi $=0,9697$

$\mathrm{R}=$ Adjust Square $=0,9637$

$\mathrm{F}_{\text {hitung }}=160,1009$

Durbin Watson Test $=1,0215$

Berdasarkan tabel di atas, hasil analisa regresi dapat ditulis dalam bentuk persamaan regresi sebagai berikut:

$\mathrm{LS}=-8.8685+0.1496 \mathrm{LY}_{\mathrm{t}}+0,0860 \mathrm{Lr}+1,1983 \mathrm{LS}_{\mathrm{t}-1}+\mathrm{e}_{\mathrm{t}}$ $(-4,1137) \quad(6,7073) \quad(2,9227) \quad(15,2672)$
Dimana masing-masing koefisien regresi variabel bebas menunjukkan besarnya perubahan yang akan terjadi pada variable dependen akibat adanya perubahan sebesar 1 satuan dari masingmasing variabel independen. Masingmasing koefisien tersebut dapat dijelaskan sebagai berikut :

$\beta_{0}=-8,8685$; berarti nilai tabungan nasional (LS) sebesar 1,3536 miliar rupiah pada saat pendapatan nasional, tingkat suku bunga riil dan tabungan nasional periode sebelumnya tidak mengalami perubahan atau konstan.

$\beta_{1}=0,1496$; koefisien regresi variabel pendapatan nasional sebesar 0,1496; berarti ada pengaruh positif antara pendapatan nasional terhadap tabungan nasional sebesar 0,1496. Jadi, apabila pendapatan nasional naik sebesar $10 \%$, maka tabungan nasional akan naik sebesar 1,496\%. Sebaliknya, apabila pendapatan nasional turun sebesar $10 \%$, maka tabungan nasional akan turun sebesar 1,496\%. Asumsi, variabel yang lain tetap.

$\beta_{2}=0,0860 ;$ koefisien regresi variabel tingkat suku bunga riil sebesar 0,0860 ; berarti ada pengaruh positif antara tingkat suku bunga terhadap tabungan nasional sebesar 0,0860. Jadi, apabila suku bunga riil naik sebesar $10 \%$, maka tabungan nasional akan naik sebesar $0,86 \%$. Sebaliknya, apabila tingkat suku bunga riil turun sebesar $10 \%$, maka tabungan nasional akan turun sebesar $0,86 \%$. Asumsi, variabel yang lain tetap.

$\beta_{3}=1,1983 ;$ koefisien regresi variabel tabungan nasional periode sebelumnya sebesar 1,1983; berarti ada pengaruh positif antara tabungan nasional periode sebelumnya terhadap tabungan nasional sebesar 1,1983. Jadi, apabila tabungan nasional periode sebelumnya naik sebesar $10 \%$, maka tabungan nasional akan naik sebesar $11,983 \%$. Sebaliknya, apabila tabungan 
nasional periode sebelumnya turun sebesar $10 \%$, maka tabungan nasional akan turun sebesar 11,983\%. Asumsi, variabel yang lain tetap.

Kemudian dari tabel yang sama diketahui pula bahwa koefisien determinasi yang disesuaikan sebesar 0.9637 yang berarti bahwa variabel terikat tabungan nasional mampu dijelaskan oleh variabel bebas pendapatan nasional, tingkat suku bunga riil, tabungan nasional periode sebelumnya sebesar $96,37 \%$ sedangkan sisanya sebesar $3,63 \%$ diterangkan oleh variabel lain yang tidak termasuk dalam model.

Dikarenakan ada kelambanan, hasil dari kofisien jangka pendek untuk pendapatan nasional sebesar 0.1496 , dan suku bunga riil sebesar 0,0860. Sedangkan koefisien jangka panjang sebagai berikut:

Untuk variabel pendapatan nasional $\left(\mathrm{Y}_{\mathrm{t}}\right)$

$$
\frac{\text { Coeficient } Y_{t}}{(1-L S(-1))}=\frac{0,1496}{(1-(1,1983))}=-7,5441
$$

Untuk variabel tingkat suku bunga riil (r)

$$
\frac{\text { Coeficient } Y_{t}}{(1-L S(-1))}=\frac{0,0860}{(1-(1,1983))}=-4,3369
$$

Berdasarkan hasil perhitungan koefisien jangka panjang dari persamaan PAM di atas, maka dapat dikemukakan bahwa dalam jangka panjang jika pendapatan nasional naik sebesar 10 persen akan mengakibatkan tabungan nasional mengalami penurunan sebesar 75,441 persen. Begitu pula sebaliknya jika terjadi penurunan pendapatan nasional sebesar 10 persen akan mengakibatkan tabungan nasional mengalami peningkatan sebesar 75,441 persen. Sedangkan untuk variabel tingkat suku bunga riil naik sebesar 10 persen akan mengakibatkan tabungan nasional mengalami penurunan sebesar 43,369 persen dan begitu pula sebaliknya jika tingkat suku bunga riil turun sebesar 10 persen akan mengakibatkan tabungan nasional mengalami peningkatan sebesar 43,369 persen.

Berdasarkan hasil perhitungan diperoleh nilai probabilitas untuk variabel pendapatan nasional, tingkat bunga riil serta tabungan nasional periode sebelumnya masing-masing sebesar 0,0000; 0,0105 dan 0,0000. Dengan membandingkan nilai koefisien dari masing-masing variabel dapat diambil kesimpulan bahwa variabel yang mempunyai pengaruh paling dominan terhadap besarnya tabungan nasional adalah tabungan nasional periode sebelumnya. Hal ini disebabkan masyarakat cenderung menganalisa tabungan yang dimiliki periode sebelumnya serta sesuai dengan model yang digunakan dalam penelitian ini yaitu model penyesuaian parsial (Partial Adjustment Model).

Variabel lain di luar variabel besarnya tabungan nasional periode sebelumnya yang memiliki pengaruh dominan terhadap besarnya tabungan nasional jika dilihat dari nilai koefisien adalah pendapatan nasional. Hal ini sesuai dengan teori Keynes yang menyebutkan bahwa semakin tinggi pendapatan nasional maka semakin banyak tabungan masyarakat.

\section{PENUTUP}

Dari analisa data koefisien determinasi $\left(\mathrm{R}^{2}\right)$ yang disesuaikan menunjukkan bahwa variasi besarnya tabungan nasional dapat dijelaskan dengan baik oleh variabel pendapatan nasional, tingkat bunga riil serta tabungan nasional periode sebelumnya sebesar $96,37 \%$ sedang sisanya $3,63 \%$ dijelaskan oleh variabel lain di luar model yang secara implisit tercermin pada variabel pengganggu. 
Dari analisa data yang telah dilakukan menunjukkan bahwa variabel pendapatan nasional, tingkat bunga riil dan tabungan nasional periode sebelumnya ternyata secara bersamasama atau serentak mempunyai pengaruh yang signifikan terhadap besarnya tabungan nasional. Hal tersebut dilihat dari F hitung sebesar 160,1009 lebih besar dari $\mathrm{F}$ table yaitu sebesar 2,84.

Variabel pendapatan nasional, tingkat suku bunga riil mempunyai pengaruh positif terhadap besarnya tabungan nasional dalam jangka pendek. Hal ini dilihat dari t hitung dari variabel pendapatan nasional 6,7073 yang lebih besar dari t tabel yaitu 2,021 dan nilai koefisien regresi sebesar 0,1496. Sedangkan untuk variabel tingkat suku bunga riil $\mathrm{t}$ hitung sebesar 2,9227 lebih besar dari t tabel yaitu 2,021 serta nilai koefisien regresi sebesar 0,0860.

Yang berarti bahwa dalam jangka pendek kenaikan pendapatan nasional dan tingkat suku bunga riil akan menyebabkan kenaikan besarnya tabungan nasional. Sedangkan dalam jangka panjang variabel pendapatan nasional, tingkat suku bunga riil mempunyai pengaruh negatif terhadap besarnya tabungan nasional. Hal ini terlihat dari nilai koefisien regresi variabel pendapatan nasional sebesar 7,5441 dan nilai koefisien regresi variabel tingkat suku bunga riil sebesar 4,3369. Yang berarti bahwa dalam jangka panjang kenaikan pendapatan nasional dan tingkat suku bunga riil akan menyebabkan penurunan besarnya tabungan nasional.

Variabel tabungan nasional periode sebelumnya mempunyai pengaruh positif terhadap besarnya tabungan nasional. Hal ini dilihat dari $\mathrm{t}$ hitung dari variabel tabungan nasional periode sebelumnya $t$ hitung sebesar 15,2672 lebih besar dari t tabel yaitu 2,021 serta nilai koefisien regresi sebesar
1,1983. Yang berarti bahwa kenaikan pendapatan nasional dan tabungan nasional periode sebelumnya akan menyebabkan kenaikan besarnya tabungan nasional.

Oleh karena dalam penelitian ini menggunakan model penyesuaian parsial maka sesuai hasil analisa data diketahui bahwa variabel besarnya tabungan nasional periode sebelumnya merupakan variabel yang paling dominan dalam mempengaruhi besarnya tabungan nasional. Namun di luar variabel tabungan nasional periode sebelumnya tersebut diketahui bahwa variabel pendapatan nasional adalah variabel yang paling dominan pengaruhnya terhadap besarnya tabungan nasional. Hal ini disebabkan karena masyarakat sebagian besar menyisihkan sebagian pendapatannya untuk ditabung setelah dikurangi dengan pengeluaran untuk konsumsi.

\section{DAFTAR PUSTAKA}

Aprilia, Madia N. 2003. Analisis FaktorFaktor yang Mempengaruhi Tabungan Nasional di Indonesia. Skripsi tidak diterbitkan. Malang: Fakultas Ekonomi Universitas Brawijaya.

Biro Pusat Statistik, 1996. Laporan Perekonomian Indonesia, Jakarta.

Boediono, 1997. Ekonomi Makro, BPFE, Yogyakarta.

D. Nachrowi, Nachrowi. 2006. Ekonometrika untuk Analisis Ekonomi dan Keuangan. Jakarta: FE-UI.

Gujarati, Damodar. 1998. Ekonometrika Dasar Terjemahan, Sumarno Zain. Jakarta: Erlangga, 
Kuncoro, Mudrajad. 1997. Ekonomi Pembangunan. Yogyakarta: UPP AMP YKPN.

Nopirin. 1986. Ekonomi Moneter. Yogyakarta: BPFE.

Mankiw, Gregory N. 2006. Pengantar Ekonomi Makro. Jakarta: Salemba Empat.

Marvel, "Tabungan Indonesia di Masa yang akan Datang" (Online) http://www.google.com/Kururue's Blogs/Blog Archive/Tabungan Indonesia di Masa yang akan Datang.htm. (diakses 09 Januari 2009)

Partadiredja, Ace. 1977. Perhitungan Pendapatan Nasional, Jakarta: PT Pustaka LP3ES Indonesia.

Purwati, Yuni. 2001. Analisis FaktorFaktor yang Mempengaruhi Tingkat Bunga Nominal. Skripsi tidak diterbitkan. Malang: Fakultas Ekonomi Universitas Muhammadiyah Malang.

Samuelson, P. A dan William D. Nordhaus, 1992. Ekonomi, Terjemahan, Jaka Wasana Erlangga, Jakarta: LPFE-UI.

Sukirno, Sadono. 1985. Ekonomi Pembangunan : Proses, Masalah, dan Kebijaksanaan. Jakarta: LPFE-UI.

$$
\text { 1996. Pengantar }
$$

Teori Makroekonomi Edisi Kedua, PT RajaGrafindo Pustaka, Jakarta.

2004. Makroekonomi Teori Pengantar. Jakarta: PT. RajaGrafindo Persada.
Saputra, Wahid. 2005. Analisis FaktorFaktor yang Mempengaruhi Tabungan dan Investasi Swasta di Indonesia Periode 1983-2003. Skripsi tidak diterbitkan. Bandung: Fakultas Ekonomi Universitas Padjajaran.

Wahyu, Wing Winarno. 2007. Analisis Ekonometrika dan Statistika dengan Eviews. Yogyakarta: UPP STIM YKPN.

Widarjono, Agus. 2005. Ekonometrika: Teori dan Aplikasi untuk Ekonomi dan Bisnis. Yogyakarta: Ekorisia. 
